\title{
Ecological Distribution of Multi-Drug Resistant Staphylococcus Aureus from Abattoirs in Port Harcourt City
}

\section{Ogbonna DN ${ }^{1 *}$ and Azuonwu TC ${ }^{2}$}

${ }^{1}$ Department of Microbiology, Rivers State University, Nigeria

2Department of Applied and Environmental Biology, Rivers State University, Nigeria

*Corresponding author: David N Ogbonna, Department of Microbiology, Faculty of Science, Rivers State University, Nigeria, Tel: +234-7061103614; Email: ogbonna.david@ust.edu.ng

\section{Research Article \\ Volume 3 Issue 1}

Received Date: December 26, 2018

Published Date: January 11, 2019

\section{Abstract}

Abattoirs are springing up in several locations within Port Harcourt to ease access to meat products as well as reduce cost of purchase and transportation. However, the presence of several pathogenic and antibiotic resistant microorganisms in abattoirs as a result of wastes generated in the process of preparations, have of recent been a public health concern as little or no care is taken in ensuring safe and proper disposal of abattoir wastes as well as purity of the service water used in abattoirs. In this study, samples (blood, water, swab and faeces) from three abattoirs in Port Harcourt were obtained and the isolation of Methicillin resistant Staphylococcus aureus was carried out using appropriate microbiological techniques. Methicillin resistance was determined using Cefoxitin and Oxacillin only while sensitivity tests were performed for other $S$. aureus isolates to different antibiotics using Gentamicin, Erythromycin, Augmentin, Ofloxacin, Cefuroxime, Ceftriaxone, Cloxacillin and Ceftazidime. Results obtained showed that MRSA was susceptible to Oxacillin with $39.6 \%$ and Cefoxitin with 44.4\% from samples collected from Tran Amadi abattoir but showed intermediate resistance to isolates from Rumuodumaya and Iwofe abattoirs. The percentage occurrence of $S$. aureus was highest among the faecal samples with 58.3\% while blood samples which is supposed to be sterile, was observed from this study to have staphylococcal counts of $1.4 \%$. The multiple antibiotic sensitivity tests showed that S. aureus isolates were susceptible to Ofloxacin with $28 \mathrm{~mm}$ as zones of inhibition; Gentamicin had $20 \mathrm{~mm}$ and Ceftriaxone had $16 \mathrm{~mm}$ while they were $100 \%$ resistant to Augmentin, Cefuroxime and Ceftazidime while erythromycin showed intermediate sensitivity. However, it was observed that out of the 144 Staphylococcus aureus isolates from the 3 sampling points, $22.2 \%$ were resistant to Cefoxitin while $26.4 \%$ were resistant to Oxacillin. This study suggests that different resistance genes may accumulate on a single mobile element, presenting a situation in which multiple antibiotic resistance can be acquired via a single genetic event. The versatility of bacterial populations in adapting to toxic environments, along with their facility in exchanging DNA, signifies that antibiotic resistance is an inevitable biological phenomenon that will likely continue to be a chronic medical problem. 
Keywords: Methicillin Resistant Staphylococcus aureus; Abattoir; Wastes; Antibiotic Sensitivity Tests

\section{Introduction}

Various activities in abattoirs generate wastes which lead to deposition of microorganisms such as Bacillus spp., Staphylococcus spp., Escherichia coli, Bacillus spp., Clostridium welchii (C. perfringes), Pseudomonas aeruginosa, Micrococcus luteus, Vibrio spp as well as Lactobacillus plantarum [1,2]. Many of them are pathogenic and in some cases, exhibit multiple antibiotic resistances. They resist the antagonistic effect of one or more antibiotics which may be natural or acquired resistance $[3,4]$. These resistance genes are sometimes borne on integrons, transposons or plasmid which may act as vectors in spreading the genes through the processes of conjugation, transduction or transformation to other bacterial species [5]. Naturally, antibiotic resistance results from the consumption of antibiotics either at higher or lower doses than normal concentration [6]. Infection by antibiotic resistant bacteria often does not respond to conventional treatment, it may take longer time to treat and, in some cases, may lead to death of the infected individual. Prominent among antibiotic resistant microbes studied are Staphylococcus aureus and those of the Enterobacteriaceae family [7].

Staphylococci are gram positive cocci that occur in clusters and are normal flora of the mucosal surfaces as well as skin of animals and humans [8]. S. aureus is catalase positive and often distinguished from other Staphylococci by its ability to produce coagulase. It is a common pathogen found in wound, skin and soft tissues and has been implicated in infections such as endocarditis, urinary tract infections, osteomyelitis, septicemia and pneumonia. Also, it has been linked to community and hospital-acquired infections [9-12]. Methicillin resistant Staphylococcus aureus (MRSA) is a group of S. aureus isolates that are resistant to methicillin, an antibiotic belonging to the class penicillins and subclass Penicillinase Stable Penicillins. Over the years, it has been the drug of choice in the treatment of S. aureus infections. However, in recent times, resistance to it has developed [13]. Two types of MRSA are mostly known to be hospitalacquired and community-acquired MRSA. However, Livestock-associated methicillin-resistant Staphylococcus aureus has been isolated from livestock in some developed countries [14,15] and from some livestock workers and persons who are immunocompromised [15].
In Nigeria, due to increased awareness, studies on the presence of MRSA from animal sources have been carried out. Overcrowding and absence of antimicrobial agents against these MRSA has been reported to be responsible for increased prevalence of LA-MRSA [16,17]. Transmission of a strain of this pathogen (MRSA CC398) from animals to humans and vice versa has also been reported by other researchers Vanderhaegen, et al. [18], Graveland, et al. [19].

Often times, meat vendors and consumers go to abattoirs to slaughter, sell and purchase meat but little or no information has been reported on the presence of pathogenic microorganisms such as $\mathrm{S}$. aureus which may also be exhibiting single or multiple antibiotic resistances. In other cases, the blood from the slaughtered animals are used in making fish feed. These scenarios expose vendors, consumers and fishes to infection by pathogenic microorganisms and in some cases, antibiotic resistant microorganisms [20]. Therefore, this study was undertaken to investigate the distribution of these microorganisms in abattoirs as well as their antibiotic resistance pattern as this will provide public health information and serve as a basis for sensitization of the public on the need for safer abattoir practices.

\section{Materials and Methods}

\section{Description of Study Area}

This study was undertaken in three different abattoirs located in the metropolitan city of Port Harcourt at TransAmadi, Rumuodumaya and Iwofe, in Rivers State, Nigeria (Figure 1). Trans-Amadi abattoir is invariably the largest and is dominated by manufacturing industries with beehive of activities. It is located at longitude $0448.442 \mathrm{~N}$ and latitude 007 2.303E. Rumuodumaya abattoir is located close to the council headquarters of Obio/Akpor Local Government Area and is located at longitude 04 ' 52 ' $48.0 \mathrm{~N}$ and latitude 7'58'20.0 E while Iwofe abattoir has only existed for less than 3 years. It is located at latitude 4 $59^{\prime} 14.0 \mathrm{~N}$ and longitude $7 \quad 16^{\prime} 12.0$ E. All the three abattoirs except that of Iwofe are located within market centers. The temperature and humidity of the area is usually high all year round. It experiences an annual rainfall of about 70\% within April and August and 22\% within September and November; dry and wet seasons occur distinctly in the area. All samples were collected between November and May 2018.
Ogbonna DN and Azuonwu TC. Ecological Distribution of Multi-Drug Resistant Staphylococcus Aureus from Abattoirs in Port Harcourt City. J Inf Dis Trav Med 2019, 3(1): 000123.
Copyright $(C)$ Ogbonna DN and Azuonwu TC. 


\section{Journal of Infectious Diseases \& Travel Medicine}

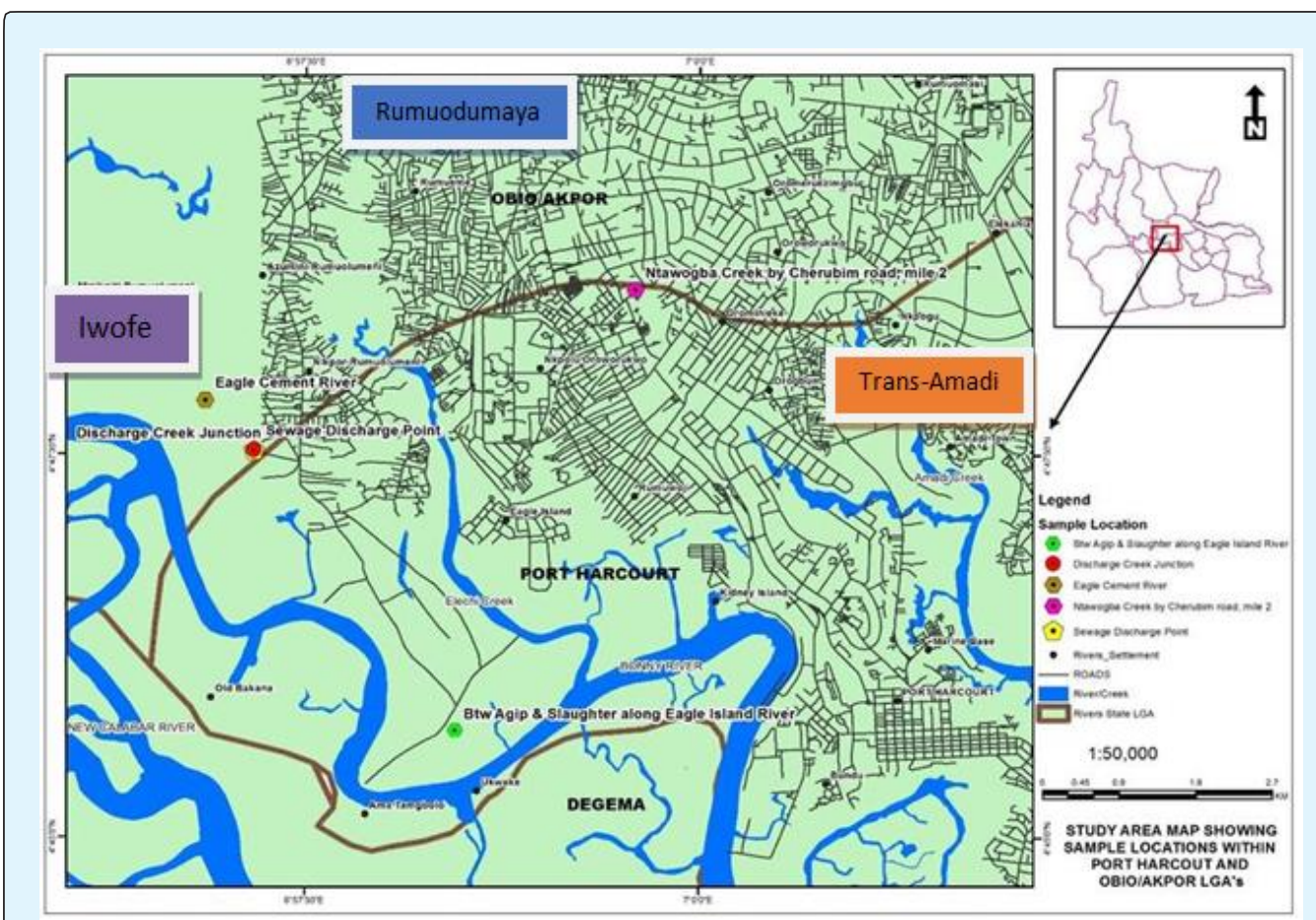

Figure 1: Map of Port Harcourt Metropolis showing the sampling points.

(Source: Rivers State Ministry of Lands and Survey, Port Harcourt)

\section{Sample Collection}

The sampling stations, sampling points' codes, sampling points' coordinates and types of samples collected are presented in Table 1. During sample collection, Global Positioning System (GPS) machine (Model GPS 76) was used for the location of the sampling points.

\begin{tabular}{|c|c|c|c|c|}
\hline \multirow{2}{*}{ Sampling stations } & \multirow{2}{*}{ Sampling points } & \multicolumn{2}{|c|}{ Sampling coordinates } & \multirow{2}{*}{ Type of samples } \\
\cline { 2 - 5 } & & Northing & Easting & Blood \\
\hline \multirow{4}{*}{ Iwofe } & $\mathrm{A}$ & $004^{\circ} 48.598^{\prime}$ & $006^{\circ} 58.517^{\prime}$ & Swab \\
\cline { 2 - 5 } & $\mathrm{B}$ & $004^{\circ} 48.592^{\prime}$ & $006^{\circ} 58.501^{\prime}$ & Water \\
\cline { 2 - 5 } & $\mathrm{C}$ & $004^{\circ} 48.601^{\prime}$ & $006^{\circ} 58.525^{\prime}$ & Faeces \\
\cline { 2 - 5 } Rumuodumaya & $\mathrm{D}$ & $004^{\circ} 48.594^{\prime}$ & $006^{\circ} 58.518^{\prime}$ & Blood \\
\cline { 2 - 5 } & $\mathrm{A}$ & $004^{\circ} 52.118^{\prime}$ & $006^{\circ} 59.580^{\prime}$ & Swab \\
\cline { 2 - 5 } & $\mathrm{B}$ & $004^{\circ} 52.102^{\prime}$ & $006^{\circ} 59.571^{\prime}$ & Water \\
\cline { 2 - 5 } & $\mathrm{C}$ & $004^{\circ} 52.124^{\prime}$ & $006^{\circ} 59.602^{\prime}$ & Faeces \\
\hline \multirow{3}{*}{ Trans-Amadi } & $\mathrm{D}$ & $004^{\circ} 48.120^{\prime}$ & $006^{\circ} 59.582^{\prime}$ & Blood \\
\cline { 2 - 5 } & $\mathrm{A}$ & $004^{\circ} 48.434^{\prime}$ & $007^{\circ} 02.303^{\prime}$ & Swab \\
\cline { 2 - 5 } & $\mathrm{B}$ & $004^{\circ} 48.456^{\prime}$ & $007^{\circ} 02.293^{\prime}$ & Water \\
\cline { 2 - 5 } & $\mathrm{C}$ & $004^{\circ} 48.444^{\prime}$ & $007^{\circ} 02.301^{\prime}$ & Faeces \\
\cline { 2 - 5 } & $\mathrm{D}$ & & \\
\hline
\end{tabular}

Table 1: Sampling points, coordinates and types of samples. 


\section{Journal of Infectious Diseases \& Travel Medicine}

\section{Blood Samples}

Blood samples of the cow were collected using a sterile $5 \mathrm{ml}$ syringe as it gushed out during slaughtering, kept in ice-packed flasks and transported to the laboratory immediately for microbiological analyses.

\section{Swab Samples}

Sterile swab sticks were used to swab the table where the slaughtered meats were kept and put in ice-packed coolers and transported to the laboratory for analyses.

\section{Faecal Samples}

Faecal samples were scooped using sterile spoons from the large intestine of the animal and put in sterile sample bottles, put in ice-packed coolers and transported to the laboratory.

\section{Water Collection}

The tap was allowed to run for a minute and then sterile sample bottles were used to collect water samples from the taps directly, put in ice-packed coolers and taken to the laboratory.

\section{Sample Preparation}

The water samples were prepared according to the method described by Chessbrough. One milliliter of the water sample was added to $9 \mathrm{ml}$ of saline solution and then a 10 -fold serial dilution was done. The process was repeated for the blood samples. For the faecal samples, 1 $\mathrm{g}$ was added to pre-sterilized and cooled $5 \mathrm{ml}$ bacteriological peptone before serial dilution was carried out. The swabs collected were dipped in $5 \mathrm{ml}$ sterilized and cooled peptone water and allowed to stand for 45 mins and from it, 10 -fold serial dilutions were done using sterilized and cooled saline solution (diluent).

\section{Microbiological Analyses}

Using standard procedures, the microbiological quality of the samples was determined. Water samples were diluted to $10^{-3}$, blood to $10^{-3}$, swabs to $10^{-5}$ and faeces to $10^{-6}$. These dilutions were determined after a pretest was carried out to determine the dilution at which the counts will be less than 300 . Aliquots $(0.1 \mathrm{ml})$ of various dilutions were transferred to prepared, cooled and surface-dried Nutrient agar and Mannitol Salt agar plates in duplicates and inoculation was done by spreading with a flamed, cooled and bent glass rod. The inoculated plates were incubated at $37^{\circ} \mathrm{C}$ for $24-48$ hours.

Ogbonna DN and Azuonwu TC. Ecological Distribution of Multi-Drug Resistant Staphylococcus Aureus from Abattoirs in Port Harcourt City. J Inf Dis Trav Med 2019, 3(1): 000123.

\section{Biochemical Characterization of $S$. aureus isolates}

The golden yellow isolates from Mannitol Salt Agar (MSA) were subculture to freshly prepared MSA plates and Nutrient agar plates and thereafter biochemical tests including Gram's staining, Catalase, citrate, glucose, galactose, maltose, mannitol, lactose, sucrose and coagulase were carried out to determine the identity of the isolates. Isolates that were confirmed to be $S$. aureus were preserved and used for further tests.

\section{Antimicrobial testing}

The susceptibility of the isolates to different antibiotics were determined using the disc diffusion method and standard sensitivity discs (Abtek Biologicals, Liverpool, UK) containing 8 antibiotics namely Gentamicin, Augmentin, Cefuroxime, Ofloxacin, Ceftazidime, Ceftriaxone, Cloxacillin and Erythromycin on each ring. Oxoid $1 \mu \mathrm{g}$ Oxacillin (Oxoid Ltd, Basingstoke, England) and Oxoid $30 \mu \mathrm{g}$ Cefoxitin (Oxoid Ltd, Basingstoke, England) discs were used to test for Methicillin Resistant Staphylococcus aureus according to the method adopted by CLSI (2017). Fresh MuellerHinton agar was prepared, the media was allowed to solidify and cool. Test isolates were diluted in $5 \mathrm{ml}$ sterilized distilled water in test tubes to a turbidity of 0.5 MacFarland's standard and then a sterile swab used to pick the diluted organism on to the prepared Mueller Hinton agar plates. The plates were allowed to stand for 5 minutes before the antibiotic sensitivity discs were picked using sterile forceps and placed on the plates. The plates were left for 30 minutes and then incubated at $37^{\circ} \mathrm{C}$ for 18-24 hours.

\section{Results}

\section{Microbiological characteristics}

A total of 144 Staphylococcus aureus isolates were randomly selected within the period of sampling and their antibiotic sensitivity patterns determined using multiple antibiotics discs. Figure 2 shows the percentage occurrence of $S$. aureus isolated between November, 2017 and October, 2018 monthly, with July 2018 recording the highest percentage occurrence with $18.1 \%$ while the least occurrence was in the month of December 2017 with $2.8 \%$. Figure 3 shows the percentage occurrence of $S$. aureus in the sampling points. Results show that TransAmadi had the highest percentage occurrence with 54.2\%, Rumuodumaya with $23.6 \%$ and Iwofe had the least count occurrence $22.2 \%$. Figure 4 shows the percentage occurrence of $S$. aureus isolates in the samples from the 


\section{Journal of Infectious Diseases \& Travel Medicine}

three abattoirs. Faeces samples $58.3 \%$, blood had the least with $1.4 \%$, Swab from tables had $23.6 \%$ and Water $16.7 \%$.

\section{Antimicrobial Susceptibility Testing}

Generally, the $S$. aureus isolates were susceptible to Ofloxacin with $28 \mathrm{~mm}$ as zones of inhibition; Gentamicin had $20 \mathrm{~mm}$ and Ceftriaxone had $16 \mathrm{~mm}$ while they were $100 \%$ resistant to Augmentin, Cefuroxime and Ceftazidime. The sensitivity test of the isolates to Oxacillin also had $16 \mathrm{~mm}$ and Cefoxitin $18 \mathrm{~mm}$ as zones of inhibition. Figure 5 shows the multiple antibiotic resistance patterns of $S$. aureus isolates from the samples. S. aureus was susceptible to Ofloxacin whose MIC value is $5 \mu \mathrm{g}$, followed by Gentamicin $(10 \mu \mathrm{g})$ and Ceftriaxone with an MIC of 30 $\mu \mathrm{g})$. Erythromycin $(5 \mu \mathrm{g})$ was susceptible to only $(0.7 \%)$ of the isolates while Augmentin (30 $\mu \mathrm{g})$ exhibited intermediate sensitivity against the isolates. It was observed that all the isolates were resistant to Ceftazidime and Cefuroxime while Cloxacillin had intermediate sensitivity against two of the isolates. In Figure 6, S. aureus isolates from Rumuodumaya sampling points showed least resistance to Oxacillin with $4.9 \%$ and Cefoxitin $4.2 \%$ while isolates from Trans-Amadi abattoir were susceptible to Oxacillin and Cefoxitin with $39.6 \%$ and $44.4 \%$ respectively while the isolates from Iwofe and Rumuodumaya abattoirs were resistant to the same antibiotics. Also, isolates from Iwofe sampling points showed resistance to Cefoxitin and Oxacillin with $8.3 \%$ and $6.9 \%$ respectively (Figure 6). However, it was observed that out of the 144 Staphylococcus aureus isolates from the 3 sampling points, $22.2 \%$ were resistant to Cefoxitin while $26.4 \%$ were resistant to Oxacillin (Figure 7).

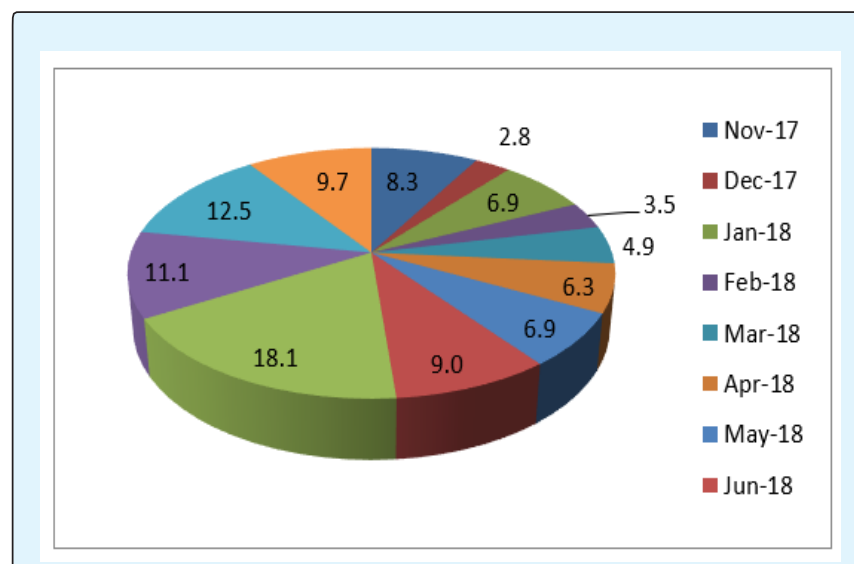

Figure 2: Percentage occurrence of Staphylococcus aureus in the different abattoir samples within the months.

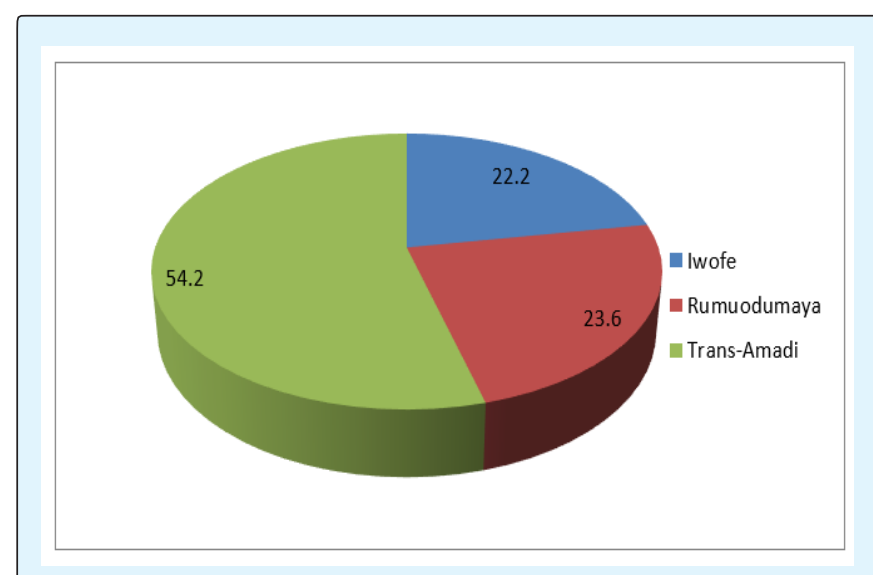

Figure 3: Percentage occurrence of $S$. aureus isolates in the three locations.

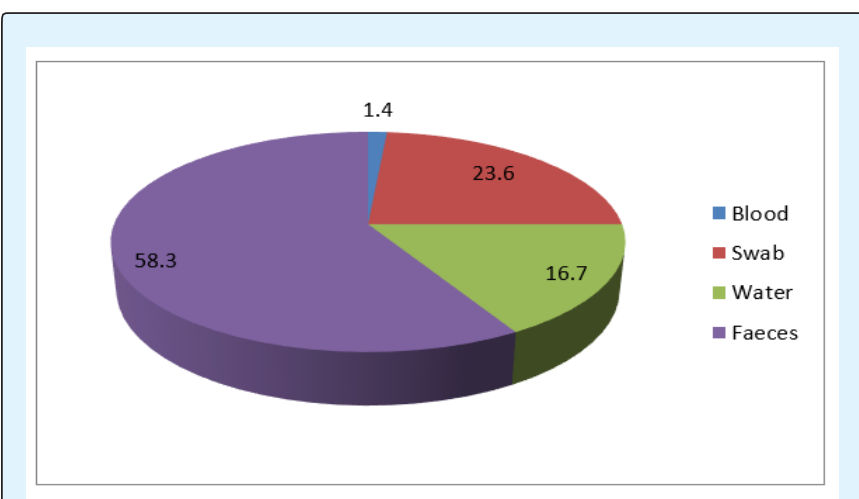

Figure 4: Percentage occurrence of $S$. aureus from all four samples.

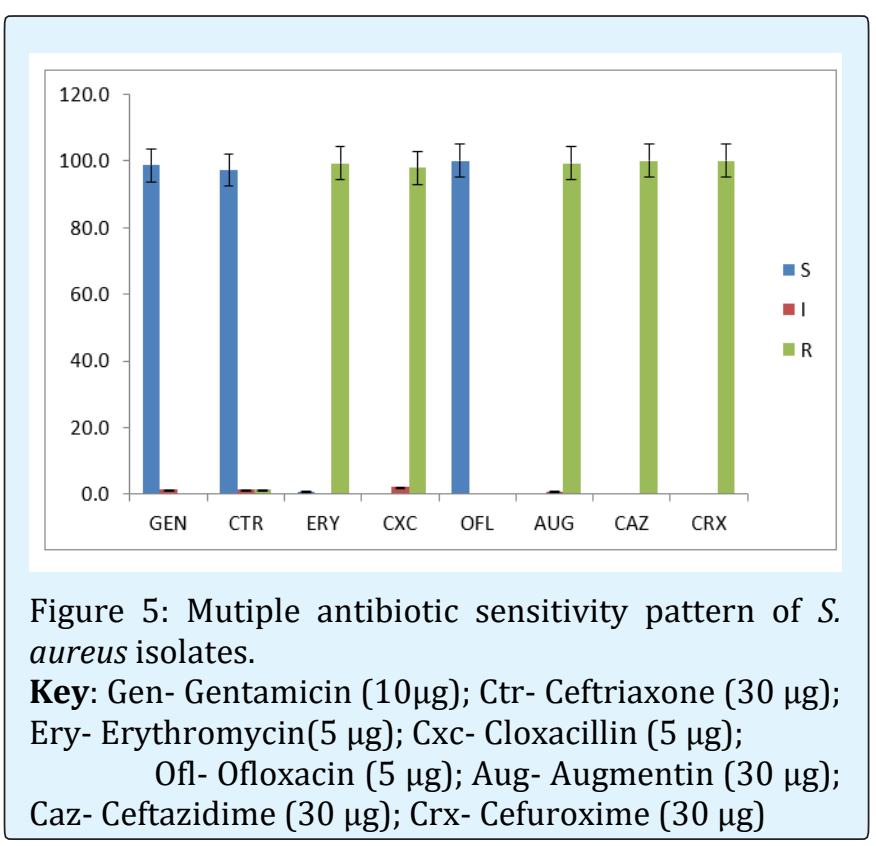




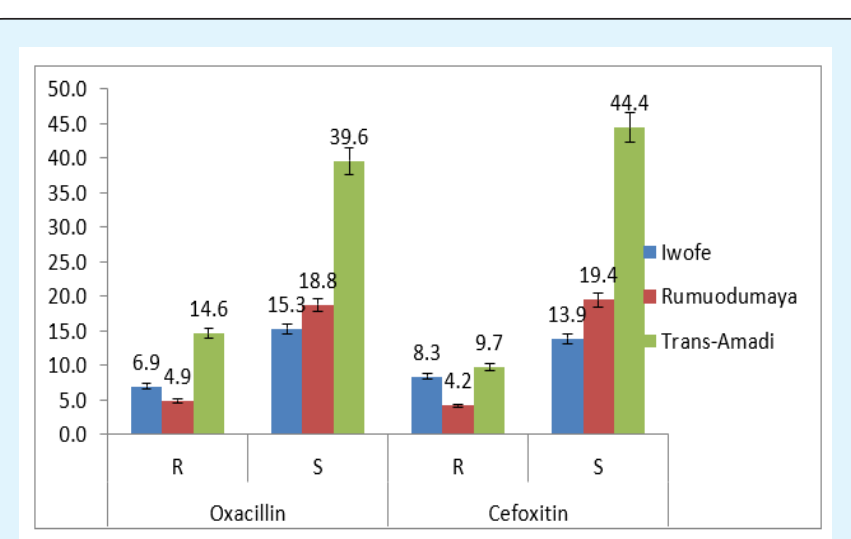

Figure 6: Percentage sensitivity of $S$. aureus isolates to Oxacillin and Cefoxitin in vitro tests.

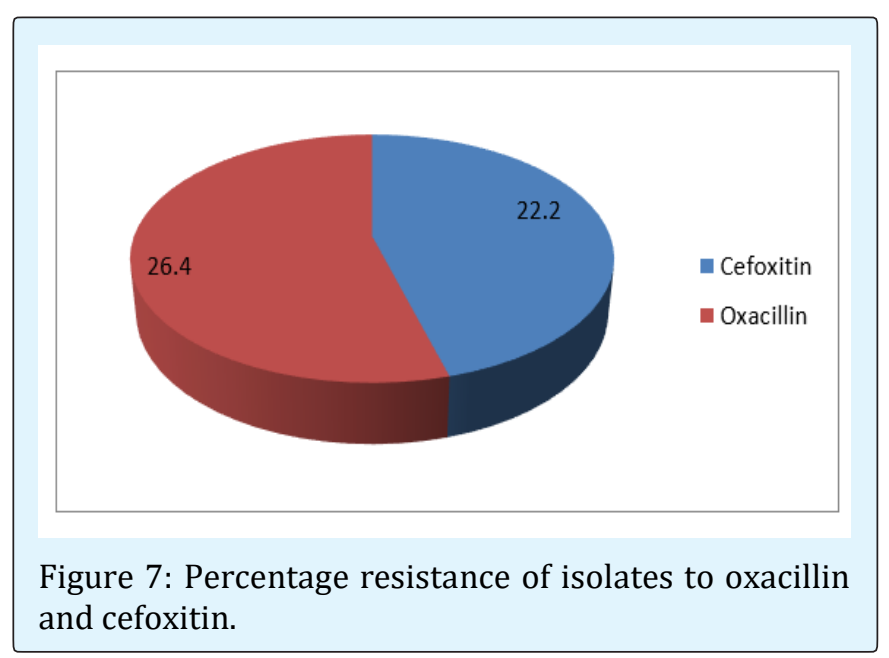

\section{Discussion}

Staphylococcus aureus is a common aetiological agent of foodborne intoxication and is a significant marker of food quality and surface cleanliness [21-23]. Various samples (blood, water, swab and faeces) were obtained from the three abattoirs and the results show that the percentage total of $\mathrm{S}$. aureus count for Iwofe $22.2 \%$, Rumuodumaya had $23.6 \%$ and Trans-Amadi $54.2 \%$. The percentage occurrence of $S$. aureus was highest among the faecal samples with $58.3 \%$ while blood samples which is supposed to be sterile, was observed from this study to have staphylococcal counts of $1.4 \%$. Its occurrence in the faecal samples may be due to the ingestion of contaminated food as these animals are often reared by open grazing before being taken to the abattoir for slaughtering. Ajayi, et al. [24] reported that this may be traceable to the faecal constituent of the wastes produced by the animals that have been treated indiscriminately with various antibiotics. The presence of $S$. aureus in blood samples may be a sign of infections (bacteremia) which may result to lethal effects in the animal if not treated. It is also possible that digestion in the rumen of the animal eventually results in the excretion of waste materials as faecal matter.

Trans-Amadi sampling point had the highest occurrence of $S$. aureus with $54.2 \%$, Rumuodumaya had $23.6 \%$ while Iwofe had the least with $22.2 \%$. In developing countries, where drugs are available to the public, self-administration or abuse of antibiotic by patients can cause increase in the prevalence of drug resistant strains [25]. Augmentin which is an Amoxicillin/Clavulanic acid is a broad-spectrum drug that is mainly used to treat community-acquired respiratory tract infections [26]. But has the risk of hepatotoxicity as an adverse effect when used frequently to treat bacterial infections including those caused by (S. aureus) Andrade, et al. [27]. However, this study showed that $98.7 \%$ of the tested isolates were resistant to Augmentin. This is in consonance with the reports of Akinpelu, et al. [28] who observed a $96 \%$ resistance to Augmentin by other microbial isolates from Obere River in Oyo State while Adebayo, et al. [29], also reported of $100 \%$ resistant rate of isolates to Augmentin from same source. In addition, it was observed that most of the isolates that were sensitive to antibiotics at first or before storage, when subsequently tested were resistant to the antibiotics. This may be due to mutation in the target site or as a result of enzymatic modification or degradation of the antimicrobials during storage, due to conditions of storage which may affect their ability to dispense activity or possible acquisition of alternative metabolic pathways to those inhibited by the drug Ogbonna, et al. [20]. Resistance of these microorganisms to some of these antibiotics may also be due to the frequent use, because numerous bacterial antimicrobial resistance phenotypes result from the acquisition of external genes that may provide resistance to an entire class of antimicrobials [30]. These genes are frequently associated with large transferable extra-chromosomal DNA elements called plasmids. Akinpelu, et al. [28] opined that the resistance of a microorganism to an antibiotic may be due to inappropriate drug use, or the ability of the organism to avoid the active ingredient in the drug. The frequent use of these antibiotics is also a possible reason; an instance is the use of antibiotics in livestock production to enhance growth [31]. However, the antimicrobial resistance observed here may be due to acquisition of resistance genes through specific proteins or through permeability changes in the bacterial cell wall/membrane, which restrict antimicrobial access to target sites and efflux 
pumps. Also, exposure to environmental pollutants and changes in nutrient composition can lead to selective pressure that favours antibiotic resistance in certain organisms [20].

Similar reports by AL-Saady, et al. [32] Adekanmbi, Falodun were observed for Ceftazidime who recorded $100 \%$ resistance for S. aureus isolated from abattoir wastewater. According to Harrison, Bratcher. Cefuroxime which is a second-generation cephalosporin has been found to have no activity against most MRSA and Pseudomonas spp. This may be linked to the presence of type $1 \beta$-lactamase in some bacteria which is able to hydrolyze some antibiotics including cefuroxime [33]. This justifies the resistance of the test isolates to cefuroxime, ceftriaxone and erythromycin in this study. This is also in agreement with the study carried out by Walsh [34] who studied the antibiogram of some isolates to second generation cephalosporins including cefuroxime. Out of the test isolates $76 \%$ were resistant to erythromycin. Erythromycin is known to act by inhibition of protein synthesis. Several authors have also reported similar findings about Staphylococcus aureus from clinical samples showing resistance of different degrees [35-37]. According to Adekanmbi, Falodun antimicrobial resistance may be plasmid-coded and this may encourage transfer of the resistance genes to once-susceptible microorganism.

Most studies make use of Oxacillin in testing for MRSA and it has been suggested as an alternative for MRSA testing as well as $\beta$-lactams resistance [38]. However, according to CLSI (2017), Oxacillin disc testing is not always reliable alone and therefore MRSA should be reported based on tests done using Cefoxitin. This is because results obtained using Cefoxitin are easier to interpret and also more sensitive in the detection of mecA-mediated resistance when compared with Oxacillin (CLSI, 2013). According to CLSI (2013), resistance and susceptibility values of Cefoxitin are $\leq 21$ and $\geq 22$ while Oxacillin has $\leq 10$ and $\geq 13$ respectively. In this study, $77.8 \%$ of the test isolates were susceptible to Cefoxitin while $22.2 \%$ were resistant to the same antibiotic. The difference in susceptibility may be attributed to the membrane permeability of the isolates to the two drugs [39]. These values are lower than those obtained by Adekanmbi, Falodun. with $63.6 \%$ resistance to Oxacillin in Ibadan and another $24 \%$ resistance of $S$. aureus to same drug in a study in Germany [31]. The concentration of the drug used against the isolates may however, be a reason for the resistance; probably an increase or decrease in the drug concentrations may render it effective against the isolates. For example, it was observed that the isolates were more susceptible to some drugs like Ofloxacin ( $5 \mu \mathrm{g}$ ) and Gentamicin $(10 \mu \mathrm{g})$ which had low MIC values than the antibiotics with higher MIC values. Another solution to this increased resistance may be the use of novel compounds different from that which has been used in producing already present antimicrobials $[40,41]$.

\section{Conclusion}

Antibiotic resistance to microorganisms has been linked to antibiotic efflux, plasmid acquisition and mutation of the microorganism. Also, exposure to environmental pollutants and changes in nutrient composition can lead to selective pressure that favors antibiotic resistance in certain organisms which has invariably led to the proliferation of antibiotic resistance Staphylococcus aureus in this study. It is therefore recommended that abattoir wastes be treated as potential sources of microbial contamination and as such be handled with care to multiple resistant strains which can cause infections.

\section{References}

1. Adesemoye AO, Opere BO, Makinde SCO (2006) Microbial content of abattoir wastewater and its contaminated soil in Lagos, Nigeria. African Journal of Biotechnology 5(20): 1963-1968.

2. Ogbonna DN (2014) Distribution of microorganism in water, soils and sediment from abattoir wastes in southern Niogeria. Int J Curr Microbiol App Sci 3(9): 1183-1200.

3. (2013) European Centre for Disease Prevention and Control (ECDC). Factsheet for experts.

4. Ogbonna DN, Inana ME (2018) Characterization and multiple antibiotic resistance of bacterial isolates associated with fish aquaculture in Pond and Rivers in Port Harcourt, Nigeria. Journal of Advances in Microbiology 10(4): 1-14.

5. Bonomo RA, Szabo D (2006) Mechanisms of multidrug resistance in Acinetobacter species and Pseudomonas aeruginosa. Clin Infect Dis 43: 49-56.

6. Diwan V, Tamhankar AJ, Khandal RK, Sen S, Aggarwal M, et al. (2010) Antibiotics and antibiotic resistant bacteria in waters associated with a hospital in Ujjain. India. BMC Public Health 10: 414.

7. Alo OS, Ojo O (2007) Use of antibiotics in food animals: a case study of major veterinary outlet in 


\section{Journal of Infectious Diseases \& Travel Medicine}

Ekiti State Nigeria. Nigeria Veterinary Journal 28: 8082.

8. Ram S, Vajpayee P, Tripathi U, Singh RL, Seth PK, et al. (2008) Resistnace and Virulence gene signatures in surface water isolates of Escherichia coli. Journal of Apllied Microbiology 105(6): 1-6.

9. Lindsay JA, Holden MT (2004) Staphylococcus aureus: Superbug, Super Genome? Trends in Microbiology 12(8): 378-385.

10. Bassetti M, Nicco E, Mikulska M (2009) Why Is Community-Associated MRSA Spreading across the World and How Will It Change Clinical Practice? Int J Antimicrob Agents 34: 15-19.

11. Taylor AR (2013) Methicillin-Resistant Staphylococcus aureus Infections. Primary Care 40(3): 637-654.

12. Zuniga R, Nguyen T (2013) Skin Conditions: Emerging Drug-Resistant Skin Infections and Infestations. American Academy of Family Physicians 407: 17-23.

13. Lewis HC, Mølbak K, Reese C, Aarestrup FM, Selchau M, et al. (2008) Pigs as source of methicillin resistant Staphylococcus aureus CC398 infections in humans, Denmark. Emerg Infect Dis 14(9): 1383-1389.

14. Van Cleef BA, Monnet DL, Voss A, Krziwanek K, Allerberger F, et al. (2011) Livestock-associated methicillin-resistant Staphylococcus aureus in humans, Europe. Emerg Infect Dis 17: 502-505.

15. Larsen J, Petersen A, Sorum M, Stegger M, van Alphen L, et al. (2015) Methicillin-resistant Staphylococcus aureus CC398 is an increasing cause of disease in people with no livestock contact in Denmark. Euro Surveill 20(37).

16. Hollis A, Ahmed Z (2013) Preserving antibiotics, rationally. N Engl J Med 369(26): 2474-2476.

17. Nadimpalli M, Rinsky JL, Wing S, Devon Hall, Jill Stewart, et al. (2015) Persistence of livestock associated antibiotic-resistant Staphylococcus aureus among industrial hog operation workers in North Carolina over 14 days. Occup Environ Med 72(2): 9099.

18. Vanderheagen W, Hermans K, Haesebrouck F, Butaye P (2010) Methicillin resistant Staphylococcus aureus
(MRSA) in food production animals. Epidemilogy and infection 138(5): 5-8.

19. Graveland H, Wagenaar JA, Bergs K, Heesterbeek H, Heederik D (2011) Persistence of livestock associated MRSA CC398 in humans is depenedent on intensity of animal contact. PubMed 9(6): e16830.

20. Ogbonna DN, Nrior R, Erheriene BA (2018) Antiobiotic resistance patterns of bacterial isolates from open drainage system in Port Harcourt, Southern Nigeria.

21. Roaska H, Wojto B (1998) In vitro effect of subinhibitory concentrations of penicillin and erythromycin on Staphylococcus aureus. Bull Vet Inst Pulawy 42: 181-188.

22. Losito P, Blaiotta G, Vergara A, Villani F, Ianieri A (2004) Characterization of Staphylococcus aureus isolated from a slaughterhouse for pigeons by RAPDPCR and REA-PFGE. In Proceedings of the 50th International Congress of Meat Science and Technology, Helsinki, Finland, pp: 660-663.

23. Normanno G, Firinu A, Virgilio S, Mula G, Dambrosio A, et al. (2005) Coagulase-positive staphylococci and Staphylococcus aureus in food products marketed in Italy. International Journal of Food Microbiology 98(1): 73-79.

24. Ajayi AO, Akonai KA (2003) Antibiotics sensitivity profile of microorganisms in Lagos lagoon, Nigeria. African Journal of Biotechnology 6: 79-84.

25. Lateef A (2004) The microbiology of a pharmaceutical effluents and its public health implications. World Journal of Microbiology and Biotechnology 22: 167171.

26. White AR, Kaye C, Poupard J, Pypstra R, Woodnutt G, et al. (2004) Augmentin (amoxicillin/clavulanate) in the treatment of community-acquired respiratory tract infection: a review of the continuing development of an innovative antimicrobial agent. J Antimicrob Chemother 1: 53-56.

27. Andrade RJ, Lucena MI, Fernández MC, Pelaez G, Pachkoria K, et al. (2005) Drug-induced liver injury: an analysis of 461 incidences submitted to the Spanish registry over a 10-year period. Gastroenterology 129(2): 512-521. 
28. Akinpelu AT, Akinlopye OM, Olukemi BC, Adegoke AE, Olayinka S (2014) Antibiotic resistant pattern of isolated bacteria from Obere River in Orile-Igbon, Oyo state, Nigeria. African Journal of Microbiology Research 8(2): 1318-1321.

29. Adebayo EA, Majolagbe ON, Ola IO, Ogundiran MA (2012) Antibiotic resistance pattern of isolated bacterial isolates from salads. Journal of Research Biology 2: 136-142

30. Baker Austin C, Wright MS, Stepanauskas R, McArthur JV (2006) Co-selection of antibiotic and metal resistance. Trends in Microbiology 14(4): 176-182.

31. Böhm R, Gözalan F, Philipp W (2004) Comparative Study on Antibiotic Resistance in Selected Bacterial Species Isolated from Wastewater Originating from Slaughterhouses and of Municipal Sources. International Society for Animal Hygièn-Saint-Malo 277.

32. AL-Sa'ady AR, Shaker W, Salam M (2014) Antibiotic Susceptibility and Heavy Metal Tolerance Pattern of Staphylococcus epidermidis, and Curing of Plasmid. Current Research in Microbiology and Biotechnology 2: 402-405.

33. Neu HC, Fu KP (1978) Cefuroxime, A Beta-LactamaseResistant Cephalosporin with A Broad Spectrum of Gram-Positive And -Negative Activity. Antimicrobial Agents and Chemotherapy 2(4): 657-664.

34. Walsh C (2000) Molecular mechanisms that confer antibacterial drug resistance. Nature 406(6797): 775781.

35. Groppo FC, Castro FM, Pacheco AB, Motta RH, Filho TR, (2005) Antimcrobial resistance of Staphylococcus aureus and oral streptococci strains from high risk endocarditis patients. Gen Dent 53(6): 410-413.

36. Hassan FSM (2011) Antimicrobial activity of erythromycin and clarithromycin against clinical isolates of Escherichia coli, Staphylococcus aureus, Klebsiella and Proteus by disc diffusin method. Pakistan Journal of Pharamceutical Sciences 23(1): 25-29.

37. Guo D, Liu Y, Han C, Chen Z, Ye D (2018) Phenotypic and molecular characteristics of methicillin-resistant and methicillin-susceptible Staphylococcus aureus isolated from pigs: Implication for livestockassociation markers and vaccine strategies. Infect Drug Resist 11: 1299-1307.

38. Kuehnert MJ, Hill HA, Kupronis BA, Tokars JI, Solomon SL, et al. (2005) Methicillin-resistantStaphylococcus aureus hospitalizations, United States. Emerg Infect Dis 11(6): 868-872.

39. Pekana A, Green E (2018) Antimicrobial Resistance Profiles of Staphylococcus aureus Isolated from Meat Carcasses and Bovine Milk in Abattoirs and Dairy Farms of the Eastern Cape, South Africa. Int J Environ Res Public Health 15(10): 2223.

40. Adebayo TBC, Adegoke AA (2008) Phytochemical and microbial screening of herbal remedies in Akwa Ibom State, South Southern Nigeria. Journal of Medicinal Plants Research 2(11): 306-310.

41. Akinjogunla OJ, Adegoke AA, Udokang IP, AdebayoTayo BC (2009) Antimicrobial potential of Nymphae lotus (Nymphaeceae) agains wound pathogens. Journal of Medicinal Plants Research 3(3): 138-141. 